\title{
TIENERMOEDERSKAP IN 'N ARM WES-KAAPSE GEMEENSKAP: NARRATIEWE OOR ONDERSTEUNING
}

\section{Doria Daniels, Elizette Nel}

\section{INLEIDING}

Tienermoederskap word in die meeste gemeenskappe gesien as 'n sosiale probleem wat 'n verskeidenheid negatiewe gevolge vir die tienerma, haar kind, haar gesin van oorsprong en die gemeenskap in die breë inhou (Cunningham, 2001; Macleod, 2004; Ribar, 1999; Strobino, 1992). Die negatiewe gevolge sluit in maatskaplike agterstande betreffende opvoeding, behuising, en werksgeleenthede. Deur tienermoederskap egter slegs as 'n misstap met baie negatiewe gevolge te beskou, word die kompleksiteit en uniekheid van elke jong vrou se ervaring ten opsigte van swangerskap en ouerskap ontken (Flanagan, 1998).

Die South African Demographic and Health Survey (SADHS), wat in 1998 onderneem is, het bevind dat 35\% van alle tieners in Suid-Afrika teen die ouderdom van 19 jaar al swanger was of 'n kind gehad het (Ellis, 2000; Swartz, 2002). Die SADHS toon verder dat die voorkoms van tienerswangerskappe in Suid-Afrika die hoogste is onder bruin en swart adolessente, veral onder dié met min of geen formele opleiding (Swartz, 2002). Sy navorsing toon voorts dat die hoë voorkoms van tienerswangerskappe verreikende gevolge in die arm en benadeelde gemeenskappe van Suid-Afrika het (Swartz, 2002). Sodanige tienermoeders is dikwels nie in staat om hul skoolloopbane te voltooi nie. Omdat hulle nie vir 'n beroep toegerus is nie is baie vasgevang in onwelkome moederskap, armoede en 'n gebrek aan geleenthede om hul volle potensiaal te verwesenlik (Departement van Welsyn en Bevolkingsontwikkeling, 1997). Volgens Nash (1992) kan om buite-egtelik gebore te word, deel vorm van 'n siklus van benadeling waaruit dit moeilik is om te ontsnap. Sy beskryf ook die babas van swart adolessente in verarmde gebiede as moontlik die mees benadeelde babas in die land. Loening (1992) bespreek onder meer die volgende ongelukkige gevolge van tienerswangerskap: vroeë terminasie van swangerskap, verlating van die baba deur die moeder, asook verwaarlosing, mishandeling en wanvoeding van die baba. Ook ander navorsing (Cunningham, 2001; Luthar, 1999; Ribar, 1999; Strobino, 1992) het bevind dat tienermoederskap mediese en sielkundige risiko's inhou vir beide die tienerma en haar baba. Dit is duidelik dat tienermoederskap 'n belangrike komponent vorm van die siklus van armoede. Voorts blyk dit ook dat tienermoederskap aansienlike risiko's vir beide die tienerma en haar baba kan meebring. Volgens Loening (1992) is die probleme van 'n tienermoeder die gevolg van veelvoudige, komplekse faktore en moet intervensie daarom 'n verskeidenheid kwessies aanspreek. Die perspektiewe van die tienermoeders self is egter afwesig in baie van die morele, politieke en mediese debatte rondom tienerswangerskap (Jewell, Tacchi \& Donovan, 2000). Tienermoederskap is 'n werklikheid in die Suid-Afrikaanse samelewing en 'n gebrek aan ondersteuningstrukture kan die ervaring vir beide die tienerma en haar baba vererger. Volgens Jewell et al. (2000) lei die afwesigheid van tieners se insette en perspektiewe ten opsigte van tienerswangerskap dikwels tot onsuksesvolle intervensies. In die artikel word gerapporteer oor die bevindinge van ' $n$ studie oor tienermoeders se perspektiewe ten opsigte van ondersteuning. Ons wou vasstel watter behoeftes tienermoeders wat in 'n lae sosio-ekonomiese woonbuurt woon, het aan ondersteuning ten einde voorstelle te maak ten opsigte van 'n gemeenskapsondersteuningsprogram om hulle ondersteuningsbehoeftes aan te spreek. 
Hierdie kwalitatiewe studie is vanuit 'n interpretivistiese paradigma benader. Volgens Babbie en Mouton (2001) is een van die mees onderskeibare kenmerke van kwalitatiewe navorsing die poging om die wêreld, of 'n spesifieke situasie, deur die oë van die deelnemers aan die studie te sien. Die doel van kwalitatiewe navorsing kan dus gedefinieer word as "beskryf en verstaan" eerder as "verduidelik en voorspel", wat die doel van kwantitatiewe navorsing is (Babbie \& Mouton, 2001). Interpretivistiese navorsingsmetodes is dus metodes wat poog om mense se gevoelens en ervarings in menslike terme te beskryf en te interpreteer en, met empatie, begrip binne konteks te verkry (Terre Blanche \& Kelly, 1999).

Die populasie vir die studie was tienermoeders woonagtig in 'n lae sosio-ekonomiese gebied in die Kaapse metropool. Daar is van doelgerigte steekproefneming gebruik gemaak aangesien inligtingryke deelnemers gesoek is. As sulks was die kriteria vir insluiting dat die tienermoeders tussen die ouderdom van 15 en 20 jaar moes wees. Tweedens moes hulle woonagtig wees in Erika ${ }^{1}$, 'n benadeelde gemeenskap in die Stad Tygerberg. Die proses van deelname is met die hulp van 'n gemeenskapswerker wat by 'n universiteitsuitreikprogram betrokke was, gefasiliteer en ses tienermoeders is as deelnemers van die studie geïdentifiseer.

Die fokusgroeponderhoud is as die primêre metode van data-insameling gebruik. Drie fokusgroeponderhoude is met die deelnemers gevoer. Die besluit om eers fokusgroeponderhoude en dan individuele onderhoude te voer het 'n morele dimensie daaraan. Die tienermoeders was jonk, semi-geskoold en broos. Ons het op fokusgroeponderhoude besluit omdat die proses veral bemagtigend kan wees en 'n stem aan sosiaal-gemarginaliseerde groepe soos tienermoeders kan gee (Morgan, 1997). Volgens Madriz (2000) is hierdie metode baie nuttig om vroue se gevoelens, houdings, hoop en drome ten opsigte van aspekte van hul lewens wat nog nie voorheen ondersoek is nie, bekend te maak. Die interaksie in die groep skep dikwels 'n bewustheid dat ander navorsingsubjekte soortgelyke ervarings of idees het, wat deelnemers se idees en ervarings bevestig en tot ' $n$ besef lei dat hulle opinies geldig is. Hierdie bevestiging bevorder dan self-openbaring en self-bemagtiging (Madriz, 2000). Die geleentheid om in besluitnemingsprosesse betrokke te wees, om as kundiges geag te word en om saam te werk in 'n navorsingsprojek, kan verder ook bemagtigend wees vir die deelnemers, soos bevind deur Goss en Leinbach (in Gibbs, 1997).

Daar is tydens semi-gestruktureerde individuele onderhoude met die deelnemers en sleutelinformante verdere duidelikheid verkry (Patton, 2002) oor die data wat uit die fokusgroeponderhoude gegenereer is. Dit was ook 'n geleentheid om sommige data wat tydens die fokusgroeponderhoude verkry is, te verifieer en om spesifieke kwessies waaroor onduidelikheid bestaan het, uit te klaar. Buiten die fokusgroep- en individuele onderhoude, is ook gebruik gemaak van 'n biografiese vraelys om agtergrondinligting oor elke deelnemer te verkry.

\section{DIE KONTEKS VAN TIENERSWANGERSKAP IN DIE WES-KAAP}

'n Ondersoek om die voorkoms van tienerswangerskap te probeer verstaan, kan nie volledig wees indien die konteks waarbinne adolessente hulle besluite oor vroeë seksuele omgang en voorbehoeding neem, nie in ag geneem word nie (Preston-Whyte \& Allen, 1992). Gedurende die laat 1980's en vroeë 1990's het die Raad vir Geesteswetenskaplike Navorsing (RGN) drie studies onderneem om tot groter begrip vir tienerseksualiteit en -swangerskap by te dra, onder meer ook in die Wes-Kaap (Preston-Whyte, 1991; Preston-Whyte \& Allen, 1992). Hierdie studies, sowel as studies van Carolissen (1993) en Howes en Green (1997), lewer 'n

\footnotetext{
${ }^{1}$ Ten einde vertroulikheid te verseker, is die naam van die woonbuurt verander.
} 
waardevolle bydrae om insig te verkry in die konteks waarbinne tienermoederskap in bruin gemeenskappe in die Wes-Kaap plaasvind.

Volgens Du Toit (in Preston-Whyte, 1991) toon tienerswangerskappe in die Wes-Kaap dieselfde patroon as in baie ander gemeenskappe en is dit, in die eerste plek, 'n sosioekonomiese verskynsel wat terselfdertyd 'n oorsaak vir, en die gevolg van, toestande van armoede en relatiewe ontneming is. Armoede, swak en oorbevolkte behuising, min ontspanningsfasiliteite in die gemeenskap en hoë vlakke van werkloosheid is van die faktore wat in die meeste van die bogenoemde studies met tienerswangerskap in verband gebring word (Howes \& Green, 1997; Preston-Whyte \& Allen, 1992). 'n Bydraende faktor wat uit die drie RGN-studies na vore gekom het en deur Carolissen (1993) ondersteun word, is die gebrek aan kennis ten opsigte van metodes van geboortebeperking en die wanopvattings daaromtrent (Preston-Whyte \& Allen, 1992) onder jong vroue. Alhoewel die deelnemers aan Carolissen se studie (1993) aangedui het dat hulle vrye toegang gehad het tot voorbehoedmiddels, het min van hulle voor hul eerste swangerskap daarvan gebruik gemaak. Die grootste rede hiervoor blyk die wanopvatting te wees dat die gebruik van voorbehoedmiddels tot onvrugbaarheid kan lei. Hierdie gebrek aan kennis kan gedeeltelik toegeskryf word aan die ernstige gebrek aan kommunikasie tussen ouers en hulle kinders ten opsigte van kwessies van seksuele gedrag (Preston-Whyte, 1991; Preston-Whyte \& Allen, 1992). Dit blyk verder dat ouers daarteen gekant was dat skole en ander instansies seksopvoeding en inligting oor metodes van voorbehoeding aan hul kinders bied (Preston-Whyte \& Allen, 1992).

Ooglopende teenstrydighede het voorgekom in die deelnemers aan bogenoemde studies se verklaarde houdings ten opsigte van voorhuwelikse seks en buite-egtelike geboortes (Carolissen, 1993; Preston-Whyte \& Allen, 1992). Die meeste van die tieners wat aan van die studies deelgeneem het, het saamgestem met die stellings dat voorhuwelikse seks "verkeerd" is en dat buite-egtelike geboortes nie deur hulle gesinne of die gemeenskap aanvaar word nie. Ten spyte hiervan het hulle aangedui dat ' $\mathrm{n}$ ongetroude moeder ' $\mathrm{n}$ normale verskynsel is, dat tienerswangerskappe en -geboortes redelik aanvaarbaar is en dat die tienermoeder en haar baba binne die gesin en gemeenskap geakkommodeer word (Carolissen, 1993; Preston-Whyte, 1991, 22). Volgens Carolissen (1993) het al die ouers van die deelnemers aan haar studie ook, ten spyte van aanvanklike ontevredenheid oor hul dogters se swangerskap, uitgebreide emosionele of finansiële ondersteuning aan hul swanger dogters verskaf.

'n Groot persentasie van die tienermoeders wat aan die Wes-Kaapse studies deelgeneem het, het aangedui dat tiener- en buite-egtelike moederskap al voorheen in hulle gesinne voorgekom het. In Carolissen (1993) se studie kon al die deelnemers ten minste een lid van hul direkte of uitgebreide familie identifiseer wat ook gedurende haar tienerjare, of voorhuweliks, swanger was of 'n kind gehad het. In Todt se studie (Preston-Whyte, 1991) was 73,3\% van die deelnemers se ma's ook ten tyde van die geboorte van hul eerste kind ongetroud. Dit blyk dus dat die voorkoms van intergenerasiepatrone van buite-egtelikheid in die Wes-Kaap hoog is. Ten spyte hiervan is dit interessant dat die meeste ouers met wie daar in Todt en Hall se studies (Preston-Whyte, 1991) onderhoude gevoer is, streng konserwatiewe sienings gekoester het oor die plek en rol van hul tienerdogters in die gesin en in die breër gemeenskap. Die ideale dogter is beskryf as een wat hulpvaardig is in die huis, nie saans uitgaan nie, haar ouers se gesag aanvaar en wie se belangstellings binne die huis is. Dit blyk dat dieselfde waardes ook vir die ideale vrou en ma geld, met die gevolg dat moederskap aan 'n tienermeisie die status gee dat sy een van die algemeen aanvaarde doelwitte van vrouwees bereik het. 
Bogenoemde studies lewer 'n waardevolle bydrae tot insig in die konteks van tienermoederskap in die Wes-Kaap, die houding van tieners ten opsigte van ouerskap en ouers se siening van die rol van hul adolessente dogters in die gesin en die gemeenskap. Dit laat egter 'n leemte ten opsigte van begrip vir die gevolge van moederskap vir die tienermeisie binne hierdie konteks en haar gepaardgaande behoeftes aan ondersteuning.

\section{DIE SES TIENERMA'S SE LEWENSOMSTANDIGHEDE}

Die kriteria vir insluiting by die studie was dat die jong vroue óf swanger, óf ma's moes wees. Hulle moes ook met die geboorte van hulle eerste kind nie ouer as 19 wees nie. Een van die deelnemers, Libby, was reeds 20 jaar oud toe die studie begin het. Sy was egter al op 18 vir die eerste maal swanger, maar het haar baba baie laat in die swangerskap verloor. Daar is besluit om haar by die studie in te sluit omdat haar ondervinding met ondersteuningstelsels as swanger tiener oor 'n langer tydperk strek. In tabel 1 word die deelnemers se biografiese gegewens ten opsigte van hulle huidige ouderdom opgesom, gevolg deur 'n bespreking hiervan.

\section{TABEL 1}

BIOGRAFIESE GEGEWENS VAN DIE MA'S

\begin{tabular}{|c|c|c|c|c|}
\hline NAAM* & OUDERDOM & BABA & $\begin{array}{c}\text { OUDERDOM } \\
\text { (IN MAANDE) }\end{array}$ & $\begin{array}{c}\text { BEPLANDE } \\
\text { SWANGERSKAP }\end{array}$ \\
\hline Linda & 18 & Marlin & 6 & Tussen-in \\
\hline Libby & 20 & $\begin{array}{c}1^{\text {ste }} \text { baba dood } \\
\text { Nadia }\end{array}$ & 2 & Ja \\
\hline Juanita & 18 & Antoinette & 1 & Ja \\
\hline Carol & 18 & $\begin{array}{c}\text { Timothy } \\
\text { Melanie }\end{array}$ & 55 & Nee \\
\hline Gogga & 17 & Sergio & 15 & Nee \\
\hline Natasha & 20 & Lee-Anne & 21 & Nee \\
\hline
\end{tabular}

*Skuilname is vir deelnemers gebruik.

Die jong vroue se ouderdomme met die geboorte van hulle babas het gewissel tussen 13 en 20 jaar. Carol was 13 toe Timothy gebore is en 16 met Melanie se geboorte. Ook Gogga was 16 met Sergio se geboorte. Natasha, Juanita en Linda was almal 18 toe hulle vir die eerste keer ma's geword het, en Libby 20. Dit was Libby se tweede swangerskap. Sy het haar eerste baba verwag toe sy 18 jaar oud was, maar het die baba op 38 weke verloor. Slegs Libby en Juanita se swangerskappe was beplan.

Wanneer die jong vroue met hulle portuurgroep vergelyk word, was feitlik almal skolasties agter toe hulle die skool verlaat het. Linda, Juanita en Gogga was byvoorbeeld twee jaar agter, Libby drie jaar en Natasha 'n jaar. Carol was 13 en in graad 7 toe sy die skool verlaat het. Sy was dus die enigste een van die deelnemers wat skolasties saam met haar portuurgroep gevorder het tot voor sy die skool verlaat het. Juanita het die skool in graad 6 verlaat, Gogga in graad 7 en Natasha en Libby in graad 9. Linda, wat die skool in graad 10 verlaat het, was die enigste deelnemer wat die Algemene Onderwys- en Opleidingsfase suksesvol afgehandel het. Tabel 2 hier onder verskaf inligting oor die skolastiese agtergrond van die deelnemers en hul werk situasie.

Flanagan (1998) wys daarop dat tienermoederskap 'n komplekse ervaring is omdat elke jong vrou vroeë moederskap vanuit haar eie unieke stel omstandighede, motiverings, en aannames 
omtrent haar wêreld en haar toekoms betree. Die bostaande agtergrondinligting oor die jong vroue bevestig dié stelling. Alhoewel die vroue in dieselfde woonbuurt grootgeword het, was hulle omstandighede verskillend. Juanita, Gogga en Natasha het eers swanger geraak nadat hulle die skool verlaat het. Linda en Libby het die skool as gevolg van hulle swangerskap verlaat. Carol het ná Timothy se geboorte teruggegaan skool toe, maar het die ervaring moeilik gevind en die skool kort daarna permanent verlaat. Geeneen van die jong vroue het ná skoolverlating enige beroepsopleiding onderneem nie. Behalwe vir Linda, was al die vroue werkloos toe die studie gedoen is. Natasha het wel ten tyde van die studie begin werk, maar het ná twee maande bedank.

TABEL 2

SKOLASTIESE AGTERGROND EN BEROEPSTATUS

\begin{tabular}{|c|c|c|c|}
\hline NAAM & $\begin{array}{c}\text { OUDERDOM TOE SKOOL } \\
\text { VERLAAT IS }\end{array}$ & GRAAD & BEROEP \\
\hline Linda & 18 & 10 & Kassier \\
\hline Libby & 18 & 9 & Werkloos \\
\hline Juanita & 14 & 6 & Werkloos \\
\hline Carol & 13 & 7 & Werkloos \\
\hline Gogga & 15 & 7 & Werkloos \\
\hline Natasha & 16 & 9 & Werkloos \\
\hline
\end{tabular}

Flanagan (1998) wys daarop dat tienermoederskap 'n komplekse ervaring is omdat elke jong vrou vroeë moederskap vanuit haar eie unieke stel omstandighede, motiverings, en aannames omtrent haar wêreld en haar toekoms betree. Die bostaande agtergrondinligting oor die jong vroue bevestig dié stelling. Alhoewel die vroue in dieselfde woonbuurt grootgeword het, was hulle omstandighede verskillend. Juanita, Gogga en Natasha het eers swanger geraak nadat hulle die skool verlaat het. Linda en Libby het die skool as gevolg van hulle swangerskap verlaat. Carol het ná Timothy se geboorte teruggegaan skool toe, maar het die ervaring moeilik gevind en die skool kort daarna permanent verlaat. Geeneen van die jong vroue het ná skoolverlating enige beroepsopleiding onderneem nie. Behalwe vir Linda, was al die vroue werkloos toe die studie gedoen is. Natasha het wel ten tyde van die studie begin werk, maar het ná twee maande bedank.

Aangesien vyf van die ses vroue werkloos was en een 'n onvoldoende inkomste verdien het, was hulle van ander afhanklik vir huisvesting. Navorsing toon dat die meeste tienermoeders binne hulle gesin van oorsprong geakkommodeer word (Howes \& Green, 1997). In die studie was dit egter net die geval vir Linda en Gogga. Linda en haar seuntjie woon in 'n tweevertrekhuisie saam met haar ouers, ouer suster en haar suster se vierjarige seuntjie. Gogga en haar seuntjie woon ook in 'n tweevertrekhuisie saam met haar ma en jonger suster. Juanita en Carol is susters en beide het aan die begin van die studie saam met die pa's van hulle kinders, Johnny en Lorenzo, en dié se families gewoon. Tydens die studie het beide se situasies egter verander en het hulle nie meer by hulle kinders se pa's gewoon nie. Albei was op daardie stadium sonder vaste huisvesting en afhanklik van hulle woonbuurt se inwoners om van aand tot aand vir hulle en hulle kinders slaapplek te gee. Libby het by haar ouma grootgeword. Met die aanvang van die studie het Libby saam met haar kind se pa, Danny, by sy familie gewoon. Hy het haar egter fisies mishandel en ná die geboorte het sy teruggetrek na haar ouma toe. Natasha het by haar tante en dié se familie gewoon. 


\section{KENNIS, RAAD EN HULP OOR BABA SE VERSORGING}

As jong onervare ouer het die tienerma kennis, raad en inligting nodig gehad om hulle kinders te versorg. Hulle moes ook vasstel hoe om dit te bekom. Hulle het hierdie ondersteuning steeds nodig. Van die ses het slegs Gogga en Linda gesê dat hulle baie leiding van hulle ma's ontvang. Juanita, daarenteen, maak grootliks staat op wat sy waarneem wat ander ma's in die gemeenskap doen. Volgens haar leer sy deur te kyk na hoe ander ma's na hulle kinders omsien, en dan volg sy hul voorbeeld. Ten opsigte van inligting oor pre- en postnatale versorging, sowel as die inligting wat die vroue nodig gehad het om hulle op die geboorteproses voor te berei, het die plaaslike kliniek en daghospitaal'n groot rol gespeel met hul opvoeding. Inligting oor hoe om te borsvoed en wanneer om die baba te voed is inligting wat hulle as voorbeelde aangehaal het. Wanneer hulle kinders siek raak, maak hulle ook hoofsaaklik van die susters by die plaaslike kliniek gebruik vir raad. 'n Ander onverwagse bron van inligting blyk die "oumensgelofies" te wees wat elke nou en dan in die gesprekke opgeduik het en waaraan al die deelnemers tot ' $n$ mate blyk te glo. Die volgende is ' $n$ tipiese voorbeeld van so 'n bygelofie oor wanneer die baba se hare vir die eerste keer gesny mag word:

Die mense! Hulle sê mos dis oumensgelofies. Jy kan die kind se hare knip, al praat hy nog nie reg nie, dan kan jy die kind se hare knip. Maar my ma sê ek moet dit nie doen nie, netnou ... hy sê al "mamma" en "pappa" en so, maar my ma bedoel hy moet reg praat hy moet ons op onse name reg noem en dan kan ons maar sy hare knip. Maar nie nou nie.

\section{ONDERSTEUNING AAN DIE TIENERMA}

Omdat die jong vroue met die uitsondering van Linda almal werkloos was, het ons ondersoek ingestel na wat hulle persoonlike ondersteuningstelsels is. Die vroue het ondersteuning heel dikwels gelykgestel aan die vervulling van hul onmiddellike materiële behoeftes. Die aankoop van persoonlike items is ook gelykgestel aan ondersteuning.

\section{HY WAT KOOP, IS DIE ONDERSTEUNER}

Die woord "koop" is dikwels net as algemene term gebruik, maar sommige deelnemers het ook spesifiek na die koop van kleertjies, kos, melk en medisyne verwys. Al die deelnemers het op die een of ander stadium tydens die onderhoude na koop verwys wanneer hulle oor ondersteuning gepraat het. Die volgende twee aanhalings uit die fokusgroeponderhoude wys hoe ander vorme van ondersteuning dikwels ondergeskik gestel is aan die koop van items vir die baba en die moeder. Natasha is gevra of Lee-Anne se pa vir haar help met die grootmaak van haar baba, waarop sy geantwoord het:

Aan die begin het hy gehelp met koop en so. Maar nie meer nie ... al wat hy nou doen hy hou vir haar ... sê nou ek is besig, dan sal hy nou vir haar hou en so. Maar hy het nou nie geld om vir haar te koop en so nie.

Dit was ook die geval met Linda se respons op die vraag of die pa van haar kind 'n ondersteuningsrol speel in sy lewe:

Hy speel 'n rol, maar nie nog rêrig nie. Hy help my nou nie koop of so nie, maar hy kyk ook, bring sy deel by.

"Koop" neem egter ook'n breër betekenis aan as net die vervulling van materiële behoeftes. Uit die onderstaande narratief van Juanita blyk dit dat die pa se gewilligheid om vir die baba te koop al dan nie, vir die ma bewys lewer van sy toewyding as pa: 
[E]k sê miskien nou, "Johnny, hier is 'n kombersie wat hulle verkoop en die mense vra soveel en soveel vir die kombersie," en hy sê nou hy het nie geld nie. En ek gaan na iemand anders toe en ek gaan leen miskien 'n tien randjie vir die kombers, ... nou vra daai persoon nou vir my "Waar's die pa dan, kan die pa dan nie die ding koop nie? Dis daai wat die mense opkyk: "Die pa gee nie om nie." Veral soos nou, as hulle nie vir jou help inkoop nie, nou check die mense nee, hy gee nie om nie.

Dit blyk verder dat om vir die baba te koop, aan 'n persoon 'n mate van outoriteit verleen, soos in die geval van Linda se ma, wat vir haar baba, Marlin, klere koop:

O: $\quad$ So, wie't gesê hy kan nou nie meer vir Marlin kom haal nie?

Linda: My ma.

O: $\quad$ Jou ma het gesê hy mag hom nie weer kom haal nie, want hy was ombeskof?

Linda: Ja, maar ek kan mos nou niks vir my ma sê nie, want my ma koop die meeste vir Marlin.

\section{FINANSIËLE ONDERSTEUNING}

Finansiële ondersteuning het ingesluit bydraes, eenmalig of op 'n gereelde basis, waarvan die deelnemers afhanklik was om hulle kinders te versorg. Van die ses vroue het net een van tyd tot tyd 'n klein finansiële bydrae van haar baba se pa ontvang. Geeneen van die pa's het hulle kinders onderhou nie. Slegs Linda het ten tyde van die studie 'n inkomste as 'n deeltydse kassier verdien, terwyl die ander vroue werkloos was. Finansiële ondersteuning is op verskillende maniere en uit verskeie oorde bekom, soos onder meer van staatstoelaes, familie, bure en selfs deur te bedel. Libby en Carol het 'n regeringstoelae van ongeveer R170 per maand vir hulle kinders ontvang, en Natasha se aansoek was nog in proses. Volgens die jong vroue is die staatstoelae egter onvoldoende om in hul behoeftes te voorsien.

Ja, ek meen, 'n one seventy is baie min, mevrou. Daai's nog nie eens 'n dag nie, dan's dit al op al. Die kinders soek brood, hulle wil mos aantrek, alles daai moet gebeur.

As sulks is diegene wat by hulle familie woon, soos Linda, Gogga en Libby, tot 'n groot mate van hulle ma's, oumas en ooms afhanklik vir finansiële ondersteuning. Juanita se enigste bron van inkomste is die geld wat sy ontvang wanneer sy daagliks naby 'n groot winkelsentrum by 'n verkeerslig staan en vir motoriste om kos of geld vra. Ook Carol vul die regeringstoelae wat sy ontvang op hierdie manier aan, terwyl Natasha grootliks van haar buurvrou afhanklik is vir geld.

Om 'n staatstoelae vir hulle babas te kry, blyk moeilik te wees. Die probleme wat die deelnemers ondervind om vir die staatstoelae aansoek te doen, is in verskeie van die onderhoude geopper. Hier volg 'n uittreksel uit Gogga se vertelling van hoekom sy nog nie 'n staatstoelae vir haar baba ontvang nie:

Gogga: Nee, by my is dit weer so, die mense wat vir ons gehelp het ... Miskien gaan ek 'n vorm [invul] ... doen 'n brief daar by haar, nou sê sy: "Right, Bellville toe." As ek by Bellville kom, dan't ek miskien die kind se kliniekkaart vergeet of so, ... of dan is dit'n afdruk. Elke keer as ek Bellville toegaan, dan is dit'n flop.

O: $\quad$ So, jy het al probeer aansoek doen?

Gogga: Ek was al drie keer in die Bellville! 
Dit het uit die onderhoud geblyk dat die persoon wat haar met die invul van die aansoekvorm gehelp het nie duidelike inligting verskaf het oor watter bewysstukke ingelewer moet word vir haar aansoek om geprosesseer te word nie. Sy het ook nie aan haar verduidelik dat sy die oorspronklike dokumente saam met die aansoek moes inlewer nie. Wat die proses vir Gogga verder bemoeilik het is dat aansoeke van ongehude moeders slegs geprosesseer word as hulle bewys kan lewer dat hulle die babas se pa's vir onderhoud gedagvaar het voordat hulle om die toelae kon aansoek doen. Hierdie probleem is deur die ander vroue beaam. Libby het egter 'n manier gevind om die probleem te omseil deur te sê dat die pa nie opgespoor kan word nie:

[E]k het aansoek gedoen. Maar ek het gesê ek weet nie waar's die kind se pa nie. Toe gee hulle my net 'n vorm, want hulle kan mos nou niks doen. Ek weet mos nou nie waar's die kind se pa nie

Uit die data blyk dit dat daar teenstrydighede by die deelnemers is ten opsigte van die betaling van onderhoud deur die pa's van hul kinders. Oor die algemeen was hulle uitgesproke daaroor dat die pa ten minste die finansiële verantwoordelikheid vir die versorging van die baba met die ma moet deel. Die meeste van hulle was egter ongemaklik met die idee om die pa vir onderhoud te dagvaar, eerstens omdat hulle "nie wil moeilikheid maak nie", maar ook omdat hofverrigtinge meer problematies vir die tienerma blyk te wees.

Kom 'n mens by die hof, nou's dit mos: Jy moet nou sê wat doen jy vir die kind. Nou sê die pa sommer: "Nee, hulle gee nie om ... hulle wil geld hê om die geld uit te drink. Hulle gaan smokkel-yarde [toe] met die geld." Dan's daai social worker sake en so gaan dit aan. Hulle maak 'n mens swak ook by die hof. Jy's te bang om hulle te gaan aangee ook.

Deur egter nie die pa vir onderhoud te dagvaar nie, verloor die tienerma's potensieel twee bronne van finansiële ondersteuning, naamlik die onderhoudgeld en die staatstoelae. Daar was teenstrydighede ten opsigte van voorstelle om die aansoekproses vir die toelae te vergemaklik. Aan die een kant was die meeste van die deelnemers dit eens dat dit baie makliker sou wees om vir die toelae aansoek te doen indien hulle nie eers die pa vir onderhoud moes dagvaar nie. Carol het egter gevoel dat dit die enigste manier is om die pa te dwing om sy verantwoordelikheid na te kom:

Dit sou makliker gewees het, maar dan kry die pa's weer lekker. Hy't nie nodig om te sorg nie ... en hy't nie nodig om te gaan werk nie.

\section{EMOSIONELE ONDERSTEUNING}

Die meeste van die jong vroue het behoefte aan emosionele ondersteuning. Dit blyk egter dat hierdie tipe ondersteuning moeilik is om te bekom in hulle onmiddellike omgewing. Een van die redes wat hiervoor geopper is, is dat hulle moederskap gesien word as hulle eie skuld en 'n lot is wat hulle moet dra sonder om te kla. Toe hulle tydens een van die fokusgroeponderhoude gevra is met wie hulle praat as hulle bekommerd is oor hulle babas, het almal hulle kop ontkennend geskud. Beide Linda en Gogga het vertel hoe hulle ma's weier om na hulle kinders om te sien as hulle moeg raak, of moedeloos is.

Dan word daar gesê ons wou die kinders gehet het. Ek kan nie eens sê nie: "Ag, mme, jinne, speel 'n bietjie met die kind," of so nie. Dan hoor ek: "Hê, jy wou die kind gehet het!"

Alhoewel hulle nie emosionele ondersteuning geniet nie, kan hulle wel op praktiese hulp van familielede en ander staatmaak. Hierdie aspek verwys na die hulp wat die deelnemers ontvang, 
veral ten opsigte van spesifieke versorgingstake soos om die baba te was en droog te maak en om die baba op te pas of vas te hou as die ma besig is. Al die deelnemers het aangedui dat hulle primêr verantwoordelik is vir die versorging van hul babas. Hulle het egter verskeie persone geïdentifiseer wat hulle bystaan, onder andere die baba se pa (Natasha, Juanita en Gogga), hulle eie ma's (Linda en Gogga) en susters (Linda, Gogga en Libby) en die pa se familie (Carol en Juanita). Natasha steun ook sterk op haar buurvrou en Linda maak staat op haar kind se oppasser.

Alhoewel Carol haar dogtertjie se primêre versorger is, word haar seuntjie deur sy ouma grootgemaak.

Timothy is nie nou eintlik meer aan my nie. Hy's meer aan sy ouma, slaap by sy ouma en so. Hy's meer oor sy ouma. Maar Melanie is net meer aan my. Sy loop al agter my aan ... is altyd saam met my. Maar hy is nog meer by sy ouma-hulle en so, omdat hulle nou vir hom grootgemaak het so van baby-tyd af.

'n Ander behoefte wat die jong vroue het, is aan vertrouelinge met wie hulle kan praat. Volgens Carol is daar niemand wat sy genoegsaam vertrou om mee te praat oor haar probleme nie:

Want sê nou jy voel dat jy wil jou hart uitpraat, miskien nou die pa is ook nog 'n probleempie, die kinders is ook nou ... nou's die pa ook nou 'n probleem, nou vertel jy miskien vir hulle. Dan vertel hulle die ander. Môre kry jy 'n stryery en dan skel hulle al die goeters vir'n mens ... so jy hou maar net vir jouself, al voel jy hoe bedruk, jy hou dit maar vir jouself. En jy probeer maar self om weer daar uit te kom.

Die voorstel dat daar ondersteuningsgroepe vir tienerma's in die gemeenskap gestig word, is gunstig begroet. Volgens Juanita sal dit haar definitief help, "want'n mens voel nie elke dag om dinge in te hou nie". Beide Libby en Carol het gesê dat deur hulle gevoelens nie met iemand te deel nie, gevaarlik kan wees vir hulle geestestoestand. Uit die informele gesprekke met die jong ma's het dit geblyk dat dit vir hulle van groot waarde was om aan die fokusgroeponderhoude deel te neem en dat dit aan hulle 'n mate van emosionele ondersteuning gebied het. Toe daar teen die einde van een sessies aan hulle verduidelik is dat daar weens die vakansie vir 'n ruk nie ontmoetings sal wees nie, was hulle ooglopend teleurgesteld en het hulle gevra of daar die volgende jaar vir die hele jaar lank so gesels kan word. Gogga wou dadelik weet wanneer ons dan weer bymekaar sou kom. So ook Linda, sodat sy kon reël om nie daardie dag te werk nie. Daar is besef dat die onderhoude vir hierdie jong vrouens veel meer as net 'n navorsingsproses was. Dit het geblyk dat hulle die fokusgroepsessies as ondersteunend beleef het.

\section{TOEGANG TOT WERK}

Al die vroue het aangedui dat hulle graag wil werk om sodoende finansiële onafhanklikheid te verkry. Nie een van hulle het enige vaardighede wat vir die werksomgewing gesog is nie. Dit het duidelik uit die gesprekke geblyk dat werk skaars is in die Wes-Kaap en dat werkservaring vereis word. Volgens Gogga moet 'n mens 'n "CV het", of moet jy iemand ken wat jou kan aanbeveel, "'n inbring-saak", soos sy daarna verwys. Dit het verder geblyk dat hulle onvoltooide skoolloopbane hulle kanse om werk te kry, verder belemmer:

Hier by IQ Foods het hulle hoeka meisies gesoek, maar as jy eers matriek klaar is, dan moet jy daai ding bring en jou CV. Matriek! Hier's ek st. 4 uit die skool uit. Matriek, hoor daar! 
Hierdie vroue stel egter nie een belang om verder skool te gaan en matriek te slaag nie. Libby en Gogga het gesê dat hulle nie in staat is om matriek te kan voltooi nie. Carol was van mening dat 'n matrieksertifikaat nie vir jou werk verseker nie; dus beskou sy dit nie as 'n belegging nie.

Dit baat tog nie. Want die matrikulante sit dan net so by die huis soos ons! Hulle kry ook swaar werk. As mens miskien nou, jou ma en pa het miskien nou geld vir jou vir kollege toe gaan of so, dan is dit nou 'n bietjie makliker om werk te kry.

Uit die gesprek wat hierop gevolg het, het dit duidelik geblyk dat die jong vroue nie die voltooiing van hulle skoolloopbane as 'n moontlikheid gesien het om hulleself beter voor te berei vir die arbeidsmark nie. Die moontlikheid van 'n werkskeppingsprojek is egter met meer entoesiasme begroet as die voorstel oor voltooiing van die skoolloopbaan. Volgens Juanita is daar aan hulle belowe dat 'n "container opgesit gaan word" wat gebruik gaan word vir werkskepping in die woonbuurt.

\section{BESPREKING}

Al ses die jong vroue wat aan die studie deelgeneem het, is afkomstig van dieselfde lae sosioekonomiese woonbuurt in die Kaapse metropool en sukkel om 'n bestaan te voer. Slegs een van die jong vroue het 'n vaste werk, terwyl drie van hulle 'n staatstoelae vir hul kinders ontvang. Nie een van hulle ontvang onderhoud van hul kinders se pa's nie. Dit maak hulle afhanklik van ander om hulleself en hul kinders te onderhou. Familielede is hul eerste bron van finansiële hulp, waarna bure en selfs vreemdelinge wat by die verkeerslig stilhou, genader word vir ondersteuning. Uit die bevindinge van die studie het dit duidelik geblyk dat hierdie jong vroue deel is van 'n armoedekultuur waarin hulle blootgestel word aan ernstige inkomste-ontneming en onstabiele werkverskaffing (Howes \& Green, 1997). Aangesien nie een van hulle hul skoolloopbane voltooi het nie en hulle beroepsvaardighede baie beperk is, loop hierdie vroue ook die gevaar om nooit toegerus te word om ekonomies selfstandig te word nie.

Dit blyk uit die studie dat die jong vroue 'n hoë waarde geheg het aan die vervulling van hul materiële behoeftes. As Maslow se hiërargie van behoeftes in ag geneem word, blyk hierdie materiële behoeftes egter basiese behoeftes te wees. In die besprekings oor ondersteuning is daar telkens na "koop" verwys as hulle grootste ondersteuningsbehoefte, terwyl ander behoeftes, byvoorbeeld hulp met die versorging van die baba, ondergeskik hieraan gestel was. Dit blyk ook dat wanneer 'n pa nie vir sy baba materiële dinge koop nie, die gemeenskap dit sien as 'n teken dat hy nie vir sy kind omgee nie. Die waarde wat aan die vervulling van materiële behoeftes geheg word, word verder beklemtoon deur die feit dat een deelnemer selfs te kenne gegee het dat haar ma, omdat sy meer vir haar baba koop, meer gesag het by besluitneming oor haar kind. Hierdie klem op die vervulling van materiële behoeftes is verstaanbaar binne die konteks van benadeling waarin die deelnemers daagliks in 'n oorlewingstryd gewikkel is om in hulle basiese behoeftes te voorsien.

Ten opsigte van die finansiële bydraes waarvan die deelnemers afhanklik is om hulle kinders te versorg, stem die bevinding dat nie een van die deelnemers onderhoud van hulle kinders se pa's ontvang nie, ooreen met ander navorsing oor hierdie onderwerp. Volgens Howes en Green (1997) verwys verskeie skrywers oor die ekonomiese gevolge van tienermoederskap daarna dat die biologiese pa óf geen onderhoud betaal nie, óf min en wisselvallig betaal. Dit blyk uit die studie dat die deelnemers glo dat die biologiese pa op die een of ander manier gedwing moet word om sy finansiële verantwoordelikhede teenoor sy kind(ers) na te kom. Hulle voel egter dat om hom vir onderhoud te dagvaar nie 'n opsie is nie, hoofsaaklik om twee redes: In die eerste plek wil hulle nie "moeilikheid maak" nie. Uit die fokusgroeponderhoude, sowel as 
informele gesprekke met die deelnemers, wil dit voorkom asof "moeilikheid" van beide die pa en sy familie verwag kan word, wat nie die moontlikheid van sosiale isolasie en fisiese geweld uitsluit nie. Die tweede rede hou verband met die ma's se vrees dat hulle tydens die hofverrigtinge onbevoeg bevind gaan word om na hul kinders om te sien en toesig oor hulle kinders mag verloor. Die deelnemers ervaar dus 'n groot mate van magteloosheid om aanspraak te maak op finansiële ondersteuning waarop hulle wetlik geregtig is.

Alhoewel alle ma's met kinders jonger as 14 jaar wat nie onderhoud van meer as R800,00 per maand ontvang nie, kwalifiseer om vir'n regeringstoelae aansoek te doen (Grapetine, 2004), het slegs drie van die deelnemers 'n toelae vir hulle kinders ontvang. Een van die redes hiervoor hou verband met die feit dat hulle eers moet bewys dat hulle 'n klag van nie-onderhoud teen die babas se pa's gelê het voordat hulle vir die toelae kan aansoek doen. As bogenoemde vrese ten opsigte van die dagvaarding van die pa in gedagte gehou word, is dit dus verstaanbaar dat sommige van die deelnemers verkies om eerder sonder die toelae klaar te kom. Die ander rede wat aangevoer is, spruit uit die administratiewe vereistes vir so 'n aansoek. Alhoewel dit te verstane is dat so 'n aansoek met baie dokumentasie gepaard gaan, blyk dit dat van die deelnemers die proses oorweldigend gevind het en daarom besluit het om dit te laat vaar.

Ten opsigte van die biologiese pa se verhouding met sy kind, het die vroue aangedui dat dit vir hulle belangrik is dat die pa sy liefde vir sy kind bewys deur gereeld tyd met die kind te spandeer. Alhoewel die jong vroue met hierdie behoefte saamgestem het, het daar egter ook teenstrydighede in hierdie verband voorgekom en het dit uit die persoonlike onderhoude geblyk dat toegang tot die kinders soms deur hulle geweier word om die pa te "straf".

Wat 'n verrassende bevinding was, was dat die meeste van die deelnemers van mening was dat hulle behoefte aan kennis, raad en inligting voldoende aangespreek word. Al die deelnemers kon iemand identifiseer vir wie hulle sou raad vra wanneer nodig. Dit het ook geblyk dat die meeste van die deelnemers waarde heg aan "oumensgelofies", of algemeen aanvaarde mites ten opsigte van die grootmaak van hulle kinders. Dit was egter interessant dat die tipe raad waarna hulle verwys het, hoofsaaklik oor die versorgingstake van die baba gehandel het. Met betrekking tot aspekte soos hoe om 'n baba te stimuleer, kennis van ontwikkelingsmylpale en ouerskapsvaardighede, het van die deelnemers aangedui dat hulle nie vir iemand hieroor vra nie, maar hulle instink volg.

Besprekings oor die deelnemers se behoefte aan emosionele ondersteuning, of aan 'n oor om te luister, het dikwels hewige reaksie ontlok. Dit blyk dat alhoewel die meeste deelnemers uitgesproke was oor hulle behoefte om soms teenoor iemand te ontlaai, hierdie behoefte nie binne hulle gesinne of in die gemeenskap aangespreek word nie. Dit wil voorkom of die gebrek aan simpatie van hulle gesinslede daaraan toegeskryf kan word dat hul swangerskap en die geboorte van hul kinders gesien word as iets wat hulle gekies het en waarvoor hulle verantwoordelikheid moet aanvaar. Ten opsigte van emosionele ondersteuning vanuit die gemeenskap, het dit geblyk dat 'n gebrek aan vertroulikheid die groot rede is waarom die deelnemers nie die vrymoedigheid het om hulle probleme met ander te bespreek nie. As die sielkundige gevolge van tienermoederskap, onder meer die hoë voorkoms van depressie by tienermoeders, in ag geneem word (Clemmens, 2002; Hudson, Elek \& Campbell-Grossman, 2000), is dit duidelik dat die voorsiening van emosionele ondersteuning verreikend kan wees vir beide die tienermoeder en haar baba. Die oënskynlike waarde wat die fokusgroepbesprekings vir die deelnemers ingehou het, stem ooreen met wat bevind is in navorsing van De la Rey en Parekh (1996) ten opsigte van gemeenskapsgebaseerde portuurgroepe as intervensie vir tienermoeders. Soos in hulle studie, het dit in hierdie studie 
ook geblyk dat die jong vroue bemagtig gevoel het deur die geleentheid om gedeelde ervarings ten opsigte van swangerskap en moederskap te bespreek en dat hulle die groep as 'n bron van sosiale ondersteuning ervaar het.

Ten opsigte van navorsing oor die praktiese hulp wat tienermoeders in die versorging van hulle babas ontvang, stem die bevindinge slegs tot'n mate ooreen met Howes en Green (1997) se studie. In hierdie studie (Howes \& Green, 1997) was net meer as die helfte van die deelnemers primêr verantwoordelik vir spesifieke versorgingstake ten opsigte van die baba, terwyl al ses deelnemers die primêre verantwoordelikheid vir bogenoemde versorging dra. Howes en Green (1997) het verder bevind dat dit hoofsaaklik die ma's van die tienermoeders was wat hulle in die versorging van hulle babas bygestaan het, terwyl dit hier geblyk het dat slegs twee van die deelnemers se ma's 'n prominente rol in die versorging van hulle babas speel. Hierdie verskille kan moontlik toegeskryf word aan die feit dat die meeste van die deelnemers aan Howes en Green se studie by hulle gesinne van oorsprong gewoon het, terwyl vier van die tienerma's in die studie nie by hulle gesinne van oorsprong gewoon het nie.

Die tienerma's was dit eens dat om 'n werk te hê en finansieel onafhanklik te wees vir hulle baie sou help in hulle taak as moeders. Soos reeds bespreek, blyk hierdie bron van ondersteuning egter buite hulle bereik te wees vanweë die hoë werkloosheidsyfers in hulle woonbuurt en die feit dat nie een van hulle hul skoolloopbane voltooi het en oor die nodige beroepsvaardighede beskik om ekonomies selfstandig te wees nie.

\section{VOORSTELLE VIR INTERVENSIE}

Die bevindinge van die studie dui daarop dat ondersteuningsprogramme ten opsigte van werkskepping, die toeganklikheid van die staatstoelae en ondersteuningsgroepe in die gemeenskap moontlik tot groter ondersteuning van tienermoeders sal bydra. Soos hierbo genoem, het nie een van die jong vroue wat aan die studie deelgeneem het hulle skoolloopbane voltooi nie en het slegs een die Algemene Onderwys- en Opleidingfase (graad 9) suksesvol afgehandel. Die meeste van hulle is dus skolasties swak toegerus om die arbeidsmark te betree en finansiële onafhanklikheid te verkry. 'n Werkskeppingsprojek in die gemeenskap, waar hierdie jong vroue sekere vaardighede kan aanleer wat hulle in staat sal stel om 'n inkomste te genereer, blyk 'n nodige geleentheid tot finansiële onafhanklikheid te wees.

Die toeganklikheid van die staatstoelae, wat moontlik vir die jong ma's die enigste stabiele bron van finansiële ondersteuning kon wees, blyk 'n verdere probleem te wees. Die proses is te gekompliseerd vir die ma's, en hul mislukkings om suksesvol aansoek te doen vir die baie nodige toelae, is 'n groot bron van frustrasie, en ontmoedig hulle. Daar is groot behoefte aan 'n hulpfasiliteit waar die vroue om hulp met aansoeke om toelae kan aanklop. Kundiges en vrywilligers in die gemeenskap wat jong ma's kan bystaan om die nodige vorms te voltooi en seker te maak dat hulle al die nodige dokumente het om die aansoek te laat prosesseer, sou moontlik daartoe kon bydra dat jong ma's die proses minder oorweldigend vind.

Die behoefte aan emosionele ondersteuning wat deur die deelnemers geïdentifiseer is, behoort effektief aangespreek te kan word deur die stigting van ondersteuningsgroepe in die gemeenskap. Alhoewel die ma's sê dat hulle deur ondervinding leer, blyk daar baie leemtes te wees in die ondersteuningsnetwerk vir die betrokke groep tienerouers. Verskeie skrywers het die waarde van hierdie ondersteuningsgroepe vir tienerouers beklemtoon (De la Rey \& Parekh, 1996; McCullough \& Scherman, 1991; Robinson, 1988). Die sukses van sodanige groepe sal egter grootliks afhang van die mate van vertroulikheid wat binne hierdie groepe gehandhaaf sal kan word. Die mate waartoe die behoeftes van die vroue in elke groep die formaat en inhoud 
van elke sessie rig, sal ook bepaal hoe effektief die groep sy ondersteuningsfunksie sal kan vervul.

\section{BIBLIOGRAFIE}

BABBIE, E. \& MOUTON, J. 2001. The practice of social research. Kaapstad: Oxford University Press.

CAROLISSEN, R.L. 1993. The social context of adolescent pregnancy: the case of Mamre. Kaapstad: Universiteit van Kaapstad. (MA-tesis).

CLEMMENS, D.A. 2002. Adolescent mothers' depression after the birth of their babies: weathering the storm. Adolescence, 37(147):551-565.

CUNNINGHAM, A.J. 2001. What's so bad about teenage pregnancy? Journal of Family Planning and Reproductive Health Care, 27(1):36-41.

DE LA REY, C. \& PAREKH, A. 1996. Community-based peer groups: an intervention programme for teenage mothers. Journal of Community and Applied Social Psychology, 6:373-381.

DEPARTEMENT VAN WELSYN EN BEVOLKINGSONTWIKKELING. 1997. White Paper for Social Welfare. Beskikbaar: www.polity.org.za/govdocs/white papers/ social97sect2.html. [Aangehaal: 26/06/2006].

ELLIS, C.S. 2000. Perceptions and thoughts on teenage pregnancy as reflected by some participants in the World Population Day Essay Competition in 1996. Beskikbaar: http://population.pwv.gov.za/downloads/reports/adolperceptions.htm. [Aangehaal:26/06/2006].

FLANAGAN, P. 1998. Teen mothers. Countering the myths of dysfunction and developmental disruption. In: COLL, C.G., SURREY, J.L. \& WEINGARTEN, K. (red) Mothering against the odds: diverse voices of contemporary mothers. New York: The Guildford Press.

GIBBS, A. 1997. Focus groups. Social research update. Beskikbaar: www.soc.surrey.ac.uk/ sru/SRU19.html. [Aangehaal: 11/10/2005].

GRAPETINE, J. 2004. Maatskaplike werker by die Departement Maatskaplike Dienste. (telefoniese onderhoud: 10 Augustus).

HOWES, F. \& GREEN, S. 1997. Buite-egtelike moederskap in die Paarl-Wellingtongebied: die tienermoeder se versorgingspotensiaal en steunstelsel. Pretoria: Raad vir Geesteswetenskaplike Navorsing.

HUDSON, D.B., ELEK, S.M. \& CAMPBELL-GROSSMAN, C. 2000. Depression, selfesteem, loneliness, and social support among adolescent mothers participating in the New Parents Project. Adolescence, 35(139):445-453.

JEWELL, D., TACCHI, J. \& DONOVAN, J. 2000. Teenage pregnancy: whose problem is it? Family Practice, 17(6):522-528.

LOENING, W. 1992. Adolescent pregnancy: a medical perspective. In: BURMAN, S. \& PRESTON-WHYTE, E. (red) Questionable issue: illegitimacy in South Africa. Kaapstad: Oxford University Press.

LUTHAR, S.S. 1999. Poverty and children's adjustment. Thousand Oaks: Sage Publications. 
MACLEOD, C. 2004. Teenage pregnancy: a problem or not? Beskikbaar: http://www.teacher.co.za/cms/article [Aangehaal: 22/08/2006].

MADRIZ, E. 2000. Focus groups in feminist research. In: DENZIN, N.K. \& LINCOLN, Y.S. (red) Handbook of qualitative research (2de uitg). Thousand Oaks: Sage Publications.

McCULLOUGH, M. \& SCHERMAN, A. 1991. Adolescent pregnancy: contributing factors and strategies for prevention. Adolescence, 26(104):809-816.

MORGAN, D.L. 1997. Focus groups as qualitative research. Thousand Oaks: Sage Publications.

NASH, E. 1992. Breaking the cycle: psychiatric aspects of illegitimacy. In: BURMAN, S. \& PRESTON-WHYTE, E. (red) Questionable issue: illegitimacy in South Africa. Kaapstad: Oxford University Press.

PATTON, M.Q. 2002. How to use qualitative methods in evaluation. Newbury Park: Sage Publications.

PRESTON-WHYTE, E. \& ALLEN, J. 1992. Teenage pregnancy in the Coloured community. In: BURMAN, S. \& PRESTON-WHYTE, E. (red) Questionable issue: illegitimacy in South Africa. Kaapstad: Oxford University Press.

PRESTON-WHYTE, E.M. 1991. Teenage pregnancy in selected Coloured and Black communities. Pretoria: Raad vir Geesteswetenskaplike Navorsing.

RIBAR, D.C. 1999. The socioeconomic consequences of young women's childbearing reconciling disparate evidence. Journal of Population Economics, 12:547-565.

ROBINSON, B. 1988. Teenage fathers. Toronto: Lexington Books.

STROBINO, D.M. 1992. Young motherhood and infant hospitalization during the first year of birth. Journal of Adolescent Health, 13(7):553-560.

SWARTZ, L. 2002. Fertility transition in South Africa. Beskikbaar: www.un.org/esa/ population/publications/completingfertility/swartzpaper.pdf. [Aangehaal: 24/07/2006].

TERRE BLANCHE, M. \& KELLY, K. 1999. Interpretive methods. In: TERRE BLANCHE, M. \& DURRHEIM, K. (red) Research in practice. Applied methods for the social sciences. Kaapstad: University of Cape Town Press.

Prof Doria Daniels, Departement Opvoedkundige Sielkunde, Universiteit van Stellenbosch, Stellenbosch, Suid-Afrika.

Me Elizette Nel, afgestudeerde MEd student, Opvoedkundige Ondersteuning, Fakulteit Opvoedkunde, Universiteit van Stellenbosch, Stellenbosch, Suid-Afrika. 